\title{
Development of Grass Root Systems as Influenced by Soil Compaction ${ }^{1}$
}

\author{
D. W. FRYREAR AND W. G. MCCULLY2
}

Agricultural Engineer, U.S. Department of Agriculture, Big Spring, Texas Professor, Texas AむM University, College Station.

\section{Highlight}

The roots of Premier sideoats grama seedlings do not penetrate a shallow compacted layer the first year. This restrictive layer, commonly found in cultivated fields being converted to grass, can be modified by tillage to permit grass roots to exploit the soil beneath these compacted layers to obtain nutrients and water.

Soil conditions must be conducive to good root growth if maximum top growth of the plant is to be realized. Considerable information is available on the forage production potential of various grass species and varieties, but little specific knowledge has been accumulated on soil physical properties as they affect the development of grass roots.

A compacted soil layer can be formed by tillage on cultivated soils or by excessive hoof traffic on grazing lands. Compacted soil layers interfere with the development of tap roots for many crop plants and with fibrous roots for grasses and cereal crops (Fiskell et al., 1968; Hidding and Van den Berg, 1960). Barton et al. (1966) found that the yield of forage and the stand of seeded grasses declined as the strength of the compacted layer increased. Soil compaction did not influence seedling emergence, but seedlings on the compacted soils grew slower and suffered a higher mortality than those on a plowed soil. Rhoades et al. (1964) found that soil bulk density increased with an increased stocking rate and that water infiltration rate declined.

\footnotetext{
${ }^{1}$ Contribution from Soil and Water Conservation Research Division, Agricultural Research Service, USDA, in cooperation with the Texas Agricultural Experiment Station, Texas A\&M University. Received August 23, 1971. 2 The assistance of Howard Taylor and James E. Box, Jr., SWC, in planning the study, and the help and advice of Richard Dudley, AERD, in chiseling the plots is appreciated.
}

Heavy stocking rates increased soil bulk density to a depth of 36 inches, but only in the 4- to 6 -inch and 12 to 24-inch depths were the differences significant.

Plant roots may be diverted horizontally when they encounter a compacted soil layer or "pan" (Taylor and Burnett, 1963; Taylor et al., 1964). The reaction of the growing point of the root to a compacted soil layer will depend on the type of crop and on such soil factors as the strength of the compacted layer and the lateral support available to the root. Wiersum (1957) reported that roots will enter compacted soil layers if the cracks or pores are larger than the root cap, but studies by Taylor and Gardner (1960) showed that roots can grow into and through a nonporous substrate provided the strength is not excessive.

The objective of this study was to determine the rooting pattern of 2-, 3-, and 5-year-old plants of sideoats grama (Bouteloua curtipendula [Michx.] Torr. var. Premier) as influenced by a compacted soil layer or "pan."

\section{Methods}

The study was conducted in west Texas on a cultivated Amarillo sandy clay loam previously planted to grain sorghum. The main treatments were (a) compacted soil, obtained by using a 10-ton road roller, (b) plowed soil to a depth of 10 inches, and (c) field density obtained by sweep tillage ( 3 to 4 inches deep) of the sorghum stubble just ahead of the planter. Sideoats grama was seeded in June 1963 at a rate of $5 \mathrm{lb}$./acre in 40 -inch rows using a 2-row tractor mounted planter. To break up the compacted layer, half of each plot was chiseled between the grass rows in the winter of 1964 .

Additional grass plantings were made in May in 1965 and in 1966 on replicated plots that were compacted, deep-plowed, or left at field density. One-half of the field density and the compacted treatments were chiseled with a vibrating chisel to a depth of 12 inches on 40 -inch centers before planting. Sideoats grama was seeded at the rate of 5 lb./acre directly over the chisel mark using a hand planter.

Soil cores 3.25 inches in diameter were taken in the grass row and at 10 and 20 inches from one side of the grass row to a depth of 18 inches in January 1968 from all subplots of all plantings. The 18 -inch cores were cut into 6 -inch segments, and all roots within a segment were separated out of the soil using small root washers. Isoweight lines of the average root weights for six samples for an individual treatment were drawn to indicate the pattern of root production within the soil profile.

In November 1968, rectangular soil blocks were taken from selected plots for observing the rooting patterns. These soil blocks were 12 inches wide, 40 inches long, and 40 to 44 inches deep.

\section{Results and Discussion}

The development of the grass root systems on the deep-plowed plots is shown in Figure 1. As the root systems developed with time, they gradually expanded throughout the upper soil profile and root weights increased in the lower depths. The $0.40 \mathrm{~g}$ isoweight line for the 1963 and the 1965 plantings is at about the same position as the $0.20 \mathrm{~g}$ isoweight line for the 1966 planting, indicating twice the production of shallow roots for the 3and 5-year-old grasses as for the 2year-old grass. The influence of 
chiseling on a deep-plowed area can be seen by comparing the yield of roots from the chiseled and the nonchiseled areas for the 1963 planting (Fig. 1). Where the area was chiseled, there was a slight increase in root weights directly below the grass plant, compared with a more lateral shallow development of the root system on the nonchiseled area. Evidently, chiseling fractured the subsoil enough to enhance root penetration (Fig. 2).

The influence of chiseling a soil at normal field density on root development is shown in Figure 3. Patterns of root development were similar for all 3 years, even though the 1963 planting was chiseled at 20 inches from the grass row in 1964; whereas, the grass was planted directly over the chisel mark in 1965 and in 1966 . In all cases, more roots were concentrated under plants growing on the chiseled area than on the nonchiseled area. Without chiseling, the grass roots were shallow with limited development throughout the soil profile. On the chiseled plots, the grass root systems developed throughout the soil profile, and the roots had access to a greater volume of soil for extracting moisture and nutrients.

When grass was planted on a compacted area, there was a gradual increase in downward development of the root system for older plantings; however, it was not nearly so great as where the compacted treatment was chiseled (Fig. 4). Chiseling the compacted layer increased the horizontal and vertical development of the grass root system.

The mature root system monoliths (Fig. 2) illustrate that sideoats grama roots do locate areas of weakness in the compacted layer and can proliferate the soil volume below the compacted zone. There are large voids in the root system that correspond to isolated zones or layers in the soil profile with apparent differences in soil density or texture. These local zones of relatively dense soil did not interfere with root proliferation around and below them. Similar results have been

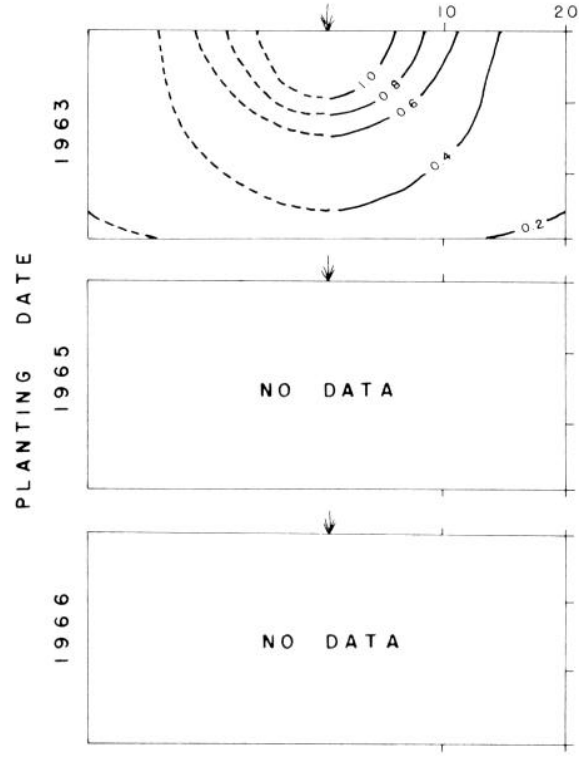

CHISELED
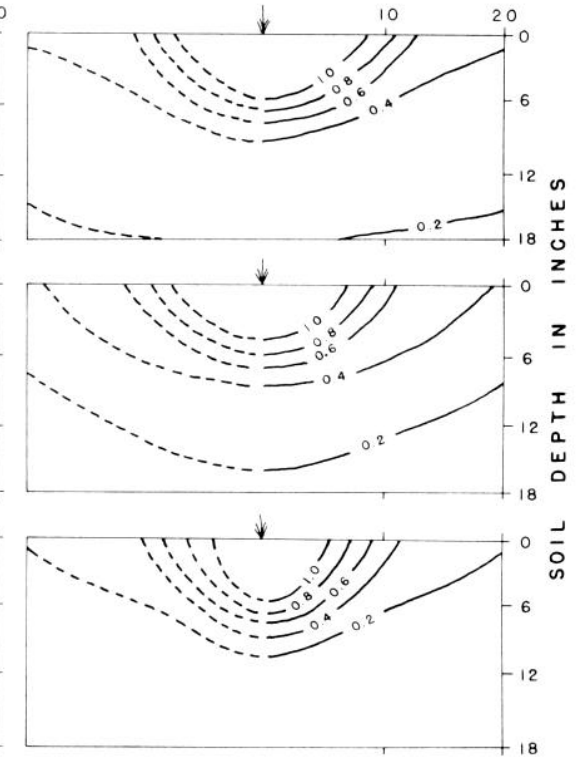

NONCHISELED
FIG. 1. Development of Premier sideoats grama grass root systems with time when planted on a deep-plowed area. Each block represents a cross section 40" wide by 18" deep. The dashed lines are a mirror image of the measured portion (solid lines) of the plant root system and are included to help illustrate the rooting pattern.

reported for maize roots (Stolzy and ment was very pronounced immeBarley, 1968).

Extensive lateral root develop- (Fig. 2). When the area was chis-
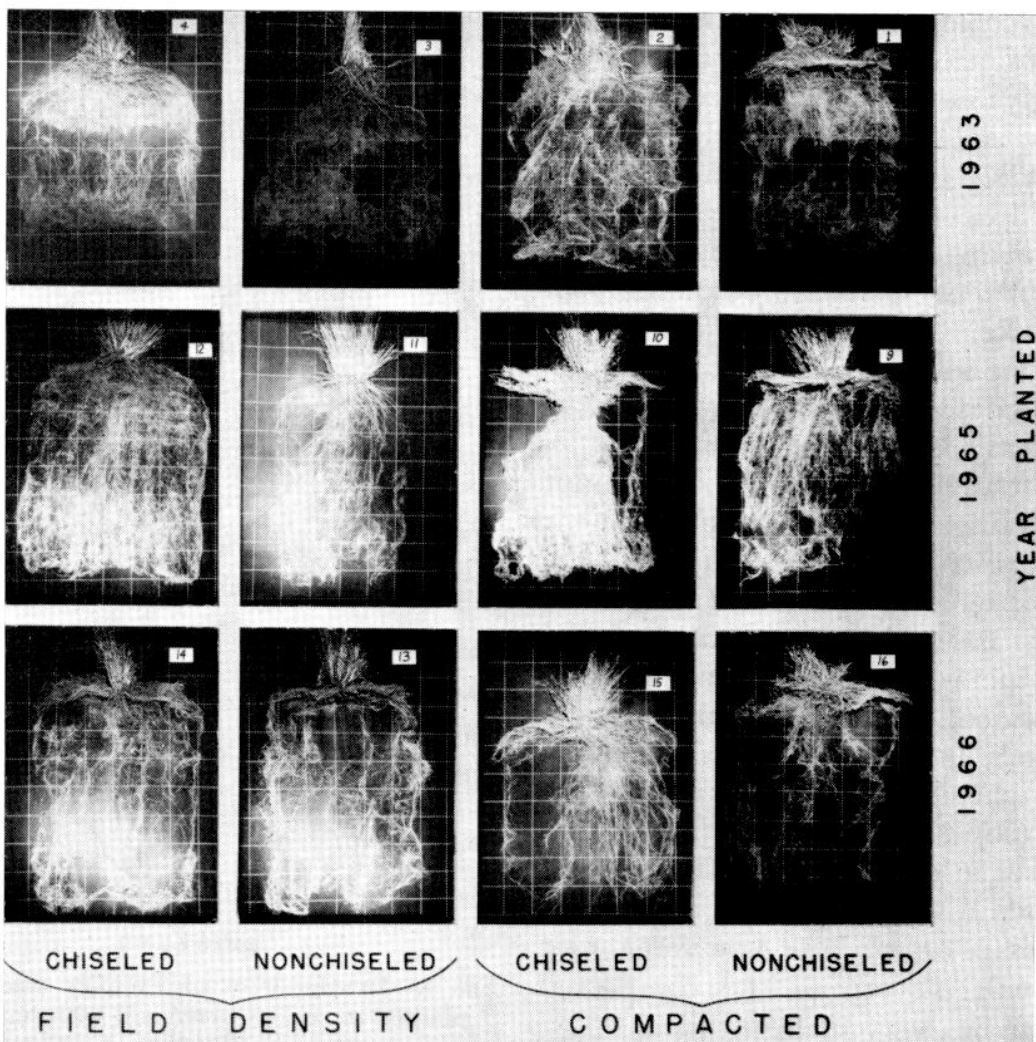

FIG. 2. Development of Premier sideoats grama grass root systems as influenced by age and soil compaction. Grid spacing in photos is 6 inches. 


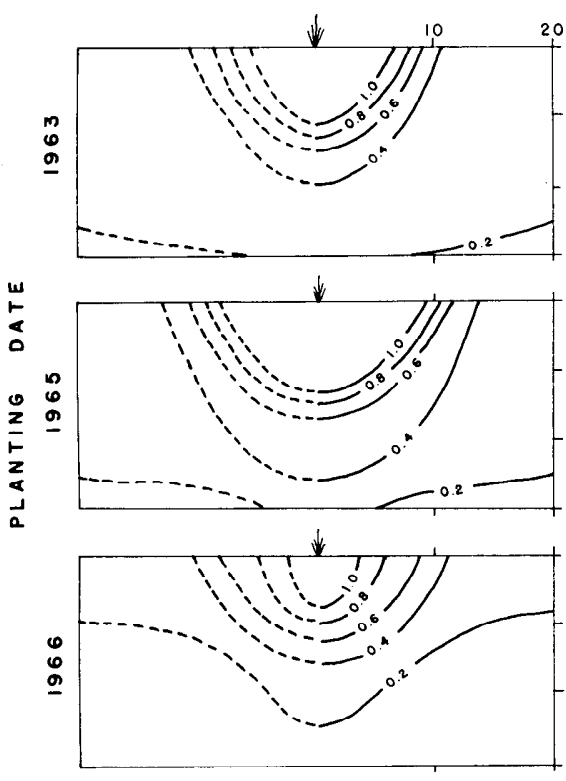

CHISELED

Fic. 3. Development of Premier sideoats grama grass root systems with time when planted on a normal field density area with half the plots chiseled. Each block represents a cross section $40^{\prime \prime}$ wide by $18^{\prime \prime}$ deep. The dashed lines are a mirror image of the measured portion (solid lines) of the plant root system and are included to help illustrate the rooting pattern.

eled, the compacted layer was fractured and there was less horizontal root development immediately above the compacted zone. Overall root proliferation was roughly equivalent for the chiseled and nonchiseled treatments.

When grasses were established on an area of normal field density, chiseling increased root development 6 to 12 inches below the soil surface.

The influence of chiseling a compacted soil and planting the grass directly over the chisel mark is quite evident (Fig. 2). Without chiseling, initial root development was restricted to the soil above the compacted layer. With time, the grass roots found areas of weakness in the compacted layer and proliferated the soil. volume immediately below the layer. When the compacted soil was chiseled, the developing grass roots followed the chisel mark down and then proliferated the soil volume below the grass plant. There was some root growth on top of the compacted layer but very little within it.

Root distribution was more uniform throughout the entire soil
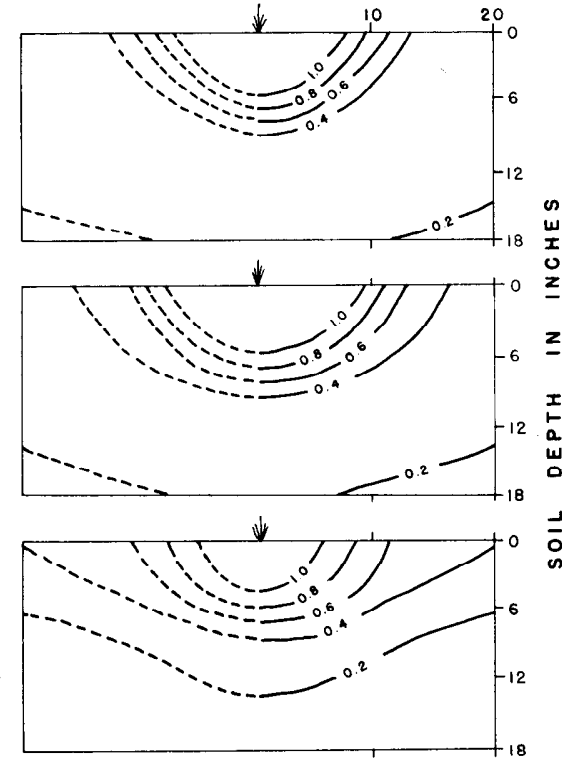

NONCHISELED
Root development for 2-year-old grasses planted on areas compacted or at field density was considerably less dense than for plants in the 3- and 5-year-old stands. The grasses developed an extensive shallow root system before penetrating the soil profile to greater depths. Grasses established on a field density soil in 1966 did not follow the chisel mark as in the 1965 planting. When the grasses were established on a compacted soil that had been chisled, the grass roots developed in the chisel mark and proliferated the soil volume below the chisel mark.

\section{Conclusions}

Isoweight drawings of root yields from small soil cores together with monoliths of intact root systems illustrate the restriction imposed on root development of Premier sideoats grama grass by compacted soil layers. If the compacted layer is not broken up, forage yield is reduced (Barton et al., 1966). Preplant tillage to break up a compacted soil zone, precision planting over a chisel mark, or chiseling an existing grass stand encouraged the growth of grass roots beneath the
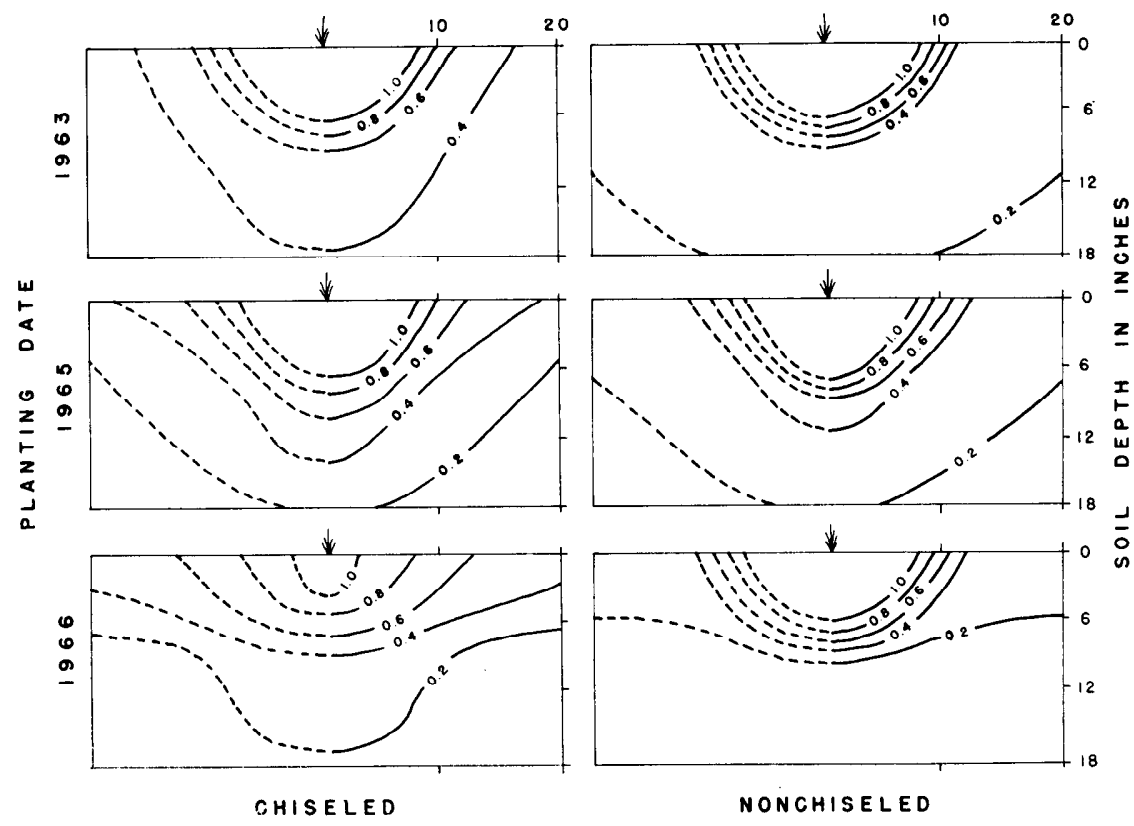

NONCHISELED

FIg. 4. Development of Premier sideoats grama grass root systems with time when planted on a compacted soil with half the plot chiseled. Each block represents a cross section 40 " wide by $18^{\prime \prime}$ deep. The dashed lines are a mirror image of the measured portion (solid lines) of the plant root system and are included to help illustrate the rooting pattern. 
compacted zone. In time, grass roots located zones of weakness in compacted layers during moist. soil conditions and penetrated into the less dense soil below.

\section{Literature Cited}

Barton, Howard, W. G. McCully, H. M. TAyior, and J. E. Box. 1966. Influence of soil compaction on emergence and first-year growth of seeded grasses. J. Range Manage. 19: 118-121.

Fiskell, J. G., V. W. Carlisle, R. Kashirad, AND C. E. Hutton. 1968. Effect of soil strength on root penetration in coarse-textured soils. 9th
Inter. Cong. of Soil Sci. Tran. 1: 794-802.

Hidding, A. P., and C. Van den Berg. 1960. The relation between pore volume and the formation of root systems in soils with sandy layers. 7th Inter. Cong. of Soil Sci. 1:369 372.

Rhoades, E. D., L. F. Locke, H. M. TAYlor, and E. H. McLlunain. 1964. Water intake on a sandy range as affected by 20 years of differential cattle stocking rates. J. Range Manage. 17:185-190.

Stolzy, L. H., ANd K. P. Barley. 1968. Mechanical resistance encountered by roots entering compacted soils. Soil Sci. 105:297-301.
Taylor, H. M., and E. BurnetT. 1963. Some effects of compacted soil pans on plant growth in the Southern Great Plains. J. Soil and Water Cons. 18:235-236.

TAylor, H. M., and H. R. Gardner. 1960. Use of wax substrates in root penetration studies. Soil Sci. Soc. Amer. Proc. 24:79-81.

TAYlor, H. M., L. F. Locke, and J. E. Box. 1964. Pans in Southern Great Plains soils, III. Their effects on yield of cotton and grain sorghum. Agron. J. 56:542-545.

WiERsum, L. K. 1957. The relationship of the size and structural stability of pores to their penctration by roots. Plant and Soil 9:75-85. 